\title{
Pengaruh treatment terhadap peningkatan produktivitas industri mikro/kecil sasaran (export oriented product) dalam rangka peningkatan daya saing industri [studi kasus : di pulau lombok-ntb]
}

\author{
I G.A.K Chatur Adhi Wirya Aryadi *, I Made Wijana, I Wayan Joniarta \\ Jurusan Teknik Mesin, Fakultas Teknik, Universitas Mataram \\ Jln. Majapahit No 62, Mataram, NTB, Kode Post 83122, Telp (0370) 6363126 \\ *Email : empatadhi@yahoo.com
}

\section{ARTICLE INFO}

Article History:

Received 10 November 2016

Accepted 15 March 2017

Available online 30 June 2017

Keywords:

Productivity

Alternative

Treatment

\section{ABSTRACT}

With the obtained value-indigo productivity on each SMEs, we can define improvement targets SMEs. By using reference values as a basis for selecting the smallest productivity of SMEs, then we can determine what we will improve. SMEs Dimas Silver and Songket gallery is a target implementation of productivity applied, because it has a partial productivity and totral smallest. Alternative workable is the addition of design and the use of EComers for both SMEs. Of the application of alternative sales increased 15\% for Dimas silver and 10\% to Songket Gallery. The impact of the increase in sales over the increased productivity of both productivity Dimas silver material partial first year of 2.86 and 3.28 for the second year. Average total productivity Songket Gallery 0.76 for the first year and 0.9 for the second year

\section{PENDAHULUAN}

Usaha Mikro, Kecil, dan Menengah (UMKM) memiliki peranan penting dalam ketahanan ekonomi nasional disaat krisis terjadi. Ketika bisnis besar gulung tikar, UMKM justru dapat menyediakan lapangan pekerjaan yang luas. Seiring perkembangan waktu, UKM menghadapi tantangan berat dengan dibukanya perdagangan bebas ASEAN-China Free Trade Agreement (ACFTA). Persaingan tidak lagi antar produk dalam negeri, tetapi juga dengan produk dari luar negeri. Di sisi lain, persaingan pasar bebas merupakan kesempatan emas bagi UKM untuk memperluas pasar.

Karena itu Renstra Kementerian Koperasi dan Usaha Kecil dan Menengah tahun 2010-2014 disusun untuk pemberdayaan UKM (Indriyanti, 2012) .Dalam pelaksanaannya, pemberdayaan UKM mengalami beberapa kendala karena kurangnya informasi yang akurat mengenai kondisi UKM. Sehingga dibutuhkan keterlibatan berbagai pihak (Pemda, Deperindag, Dinas Koperasi, Perguruan Tinggi, dan Pelaku UKM) untuk memetakan kondisi detail UKM.

\section{Konsep Produktivitas}

Produktivitas lebih dari sekedar ilmu pengetahuan, teknologi dan manajemen, karena itu produktivitas mengandung pula falsafah dan sikap mental yang selalu termotivasi pada pengembangan diri menuju kehidupan hari esok yang lebih baik. Untuk itu produktivitas pada konsepnya berhubungan dengan berbagai faktor, baik yang berada pada sumber daya manusia itu sendiri maupun faktor-faktor di luar dirinya. Para ahli tidak memberikan rumusan produktivitas yang sama, untuk itu masih ditemukan pengertian 
produktivitas dalam berbagai cara namun pada prinsipnya mempunyai kesamaan.

Produktivitas $=\frac{\text { Jumlah keluaran }}{\text { Jumlah pemasukan }}$

Pengertian produktivitas menurut Dewan Produktivitas Nasional (1983), produktivitas mengandung sikap mental yang selalu mempunyai pandangan bahwa kehidupan hari ini harus lebih baik dari kemarin dan hari esok lebih baik dari hari ini. Selain itu Dewan Produktivitas Nasional memberikan pengertian bahwa produktivitas merupakan perbandingan antara hasil yang dicapai dengan keseluruhan sumber daya yang dipergunakan, dengan perumusan (1). Produktivitas yang tinggi adalah pencapaian level tertinggi dari keluaran (efektivitas) dengan pemakaian sumber daya yang menurun (efisiensi), Arman (2000). Dengan demikian dapat dikatakan bahwa ada dua bagian yang mempengaruhi tingkat produktivitas yaitu efektivitas dan efisiensi dengan formula (2):

Produktivitas $=\frac{\text { Efektivitas }}{\text { Efisiensi }}$

Dengan demikian peningkatan produktivitas dapat dilakukan dengan jalan :

1. Pengurangan penggunaan sumber daya untuk memperoleh jumlah produksi yang sama.

2. Pengurangan penggunaan sumber daya untuk memperoleh jumlah produksi yang lebih besar.

3. Penggunaan jumlah sumber daya yang lebih besar untuk memperoleh jumlah produksi yang jauh lebih besar lagi.

4. Penggunaan jumlah sumber daya yang sama untuk memperoleh jumlah produksi yang lebih besar lagi.

\section{Pengukuran Produktivitas}

Model pengukuran produktivitas yang paling sederhana adalah pendekatan rasio output/input (Gaspersz, 1998). Pengukuran produktivitas berdasarkan pendekatan rasio output/input akan mampu menghasilkan tiga jenis ukuran produktivitas, yaitu: (1) produktivitas parsial, (2) produktivitas faktor-total, dan (3) produktivitas total.

Produktivitas parsial sering disebut juga sebagai produktivitas faktor tunggal (single- factor productivity) merupakan rasio output terhadap salah satu jenis input, Tanto dkk.(2012). Produktivitas faktor-total merupakan rasio output bersih terhadap banyaknya input modal dan tenaga kerja yang digunakan. Output bersih (net output) adalah output total dikurangi proses produksi. Produktivitas total merupakan rasio output total terhadap input total, Sumanth (1985). Berdasarkan definisi ini tampak bahwa ukuran produktivitas total merefleksikan dampak penggunaan semua

\section{METODOLOGI PENELITIAN Kerangka Konseptual}

Secara konseptual studi dilaksanakan dalam kurun waktu 2 tahun. Metode yang digunakan adalah metode uraian (deskriptif) dan pendekatan rasio output/input untuk pengukuran produktivitas. Pengumpulan data dilaksanakan dengan observasi lapangan untuk mendapatkan data sekunder dan primer. Data yang dikumpulkan adalah data historis (input dan output) industri mikro/kecil selama 36 bulan.

Berdasarkan hasil penelitian tahun ke-1, maka pada tahun ke-2 (2016) akan dilakukan perencanaan produktivitas, dan peningkatan produktivitas. Yang mana Mapping dan Nilai produktivitas terendah dari tiap UKM yang diperoleh pada penelitian tahun ke-1, akan jadikan target perbaikan produktivitas pada tahun ke-2, melalui perencanaan produktivitas dan langkah langkah peningkatan produktivitas, yang mana nantinya dievaluasi apakah langkahlangkah tersebut dapat efektif meningkatkan produktivitas UKM dan diharapkan terjadi peningkatan rasio produktivitas total dan parsialnya.

Luaran yang ingin dicapai dalam studi di tahun kedua (2) adalah kluster industri berdasarkan prioritas produktivitas, blue print peta kebijakan pemberdayaan industri. Adapun tahapan studi di tahun kedua (2) seperti gambar 1 dengan penjelasan sebagai berikut: 


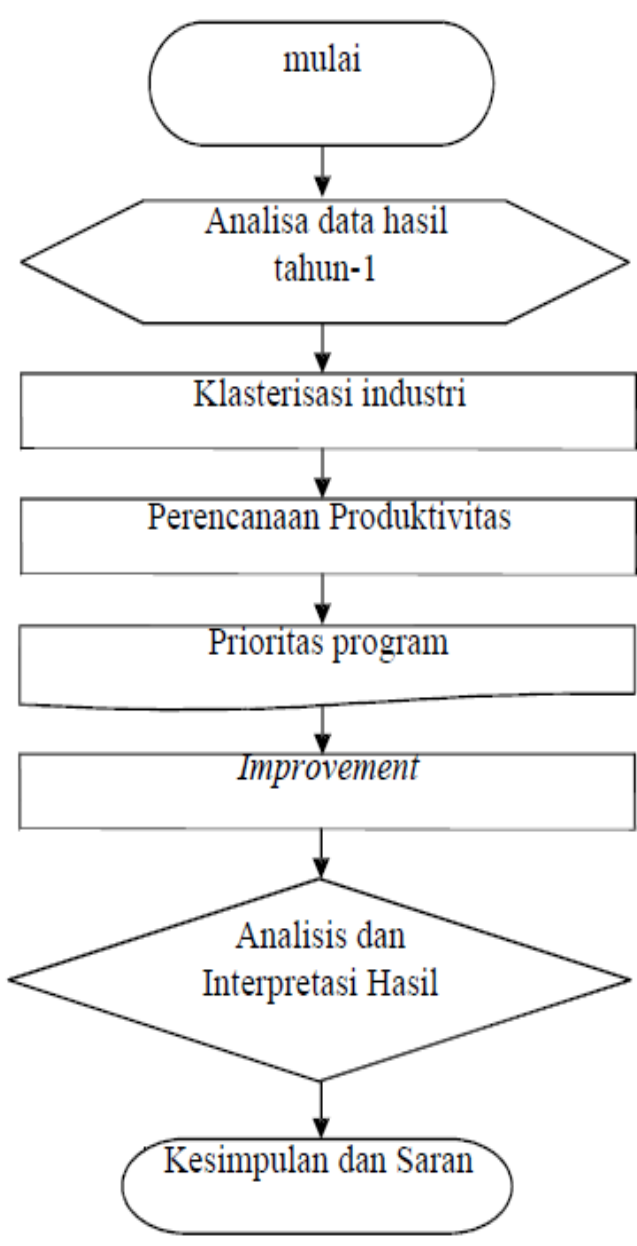

Gambar 1. Diagram alir metodologi penelitian tahun ke 2

\section{HASIL YANG DICAPAI}

Grafik dibawah menunjukkan posisi UKM dimas silver memiliki tingkat produktivitas partial material terendah. Hal ini terlihat dari penggunaan material perak akibat order yang didapat.

Setelah dilakukan pembenahan dengan menambah disain dan pemasaran yang baik terlihat adanya jumlah penggunaan material perak yang merupaka indicator bertambahnya jumlah pemesanan pada tahun berikutnya.

Untuk tingkat produktivitas total UKM songket tradisi memiliki produktivitas terendah, seperti terlihat pada gambar 4.

Peningkatan produktivitas total setelah dilakukan perbaikan disain, pewarnaan dan ergonomic proses produksi untuk UKM Songket Tradisi Galeri dapat dilihat pada gambar 5.

\section{Alternative Implementasi Produktivitas}

Implementasi yang dilakukan pada UKM

Dimas Silver adalah dengan beberapa cara,

Antara lain:

1. Meningkatkan jumlah penjualan produk

2. Meningkatkan kenyamanan kerja

3. Meningkatkan harga produk

4. Menambah design produk

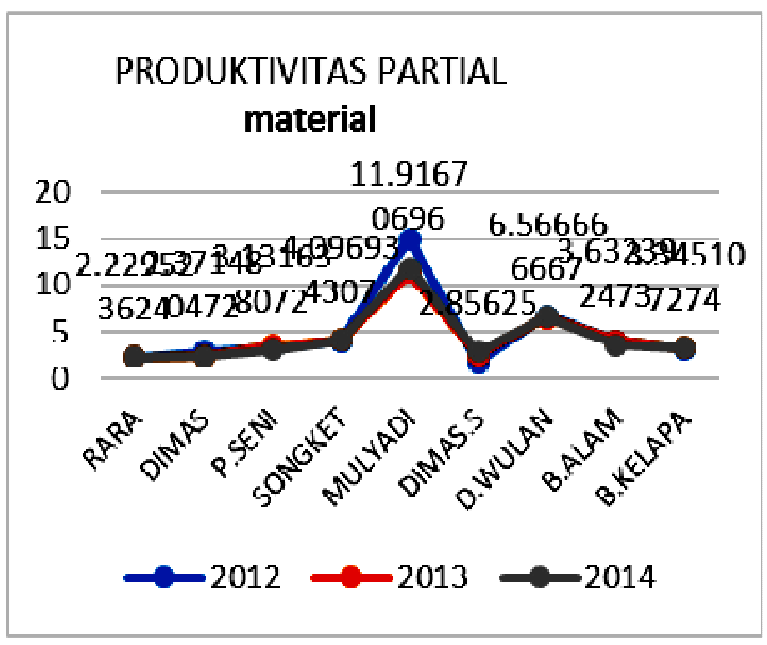

Gambar 2. Produktivitas partial UKM (Dimas Silver terkecil)

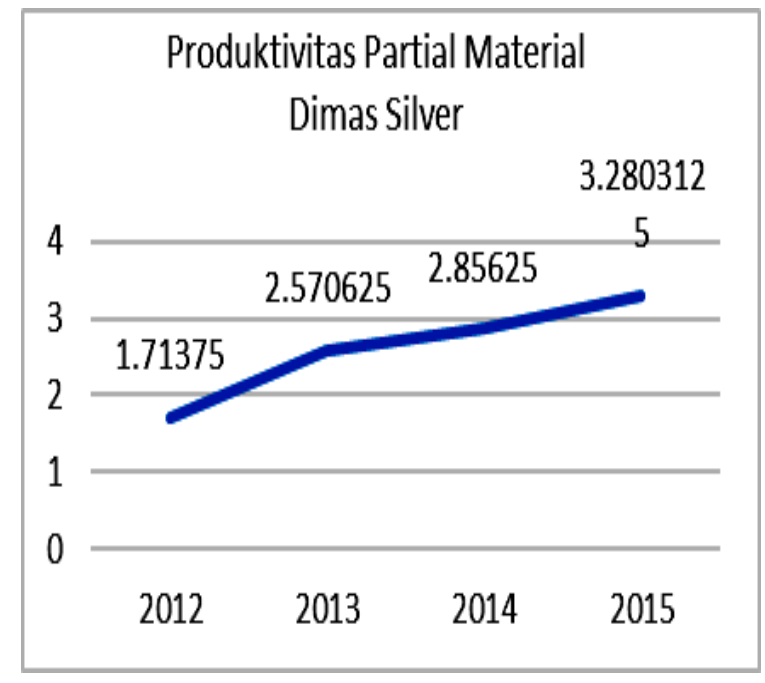

Gambar 3. Produktiftas partial materiai untuk Dimas Silver 


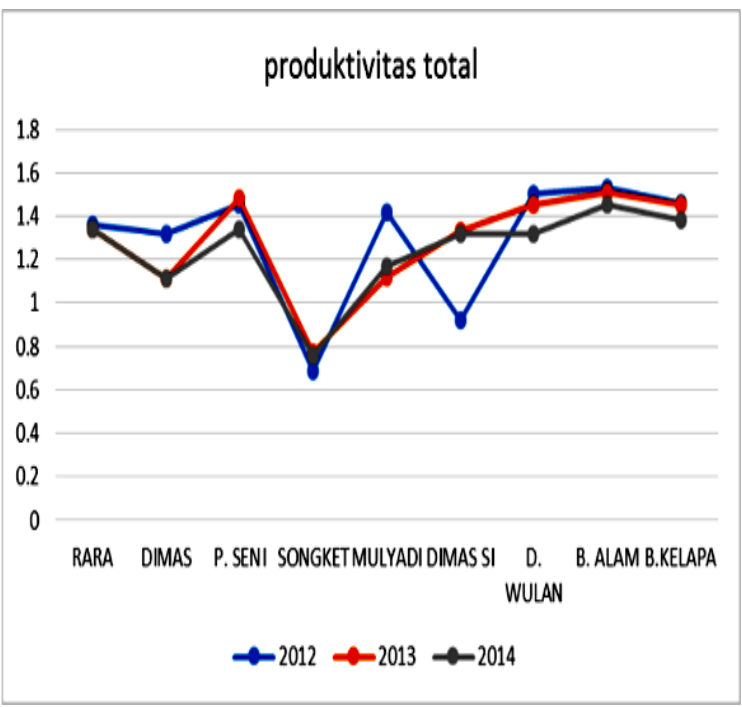

Gambar 4. Produktivitas total semua UKM

Untuk bisa meningkatkan kapasitas penjualan suatu produk diperlukan elemen penunjang. Adapun elemen penunjang itu bisa kita jabarkan sebagai berikut:

1. Promosi, ini adalah cara cara penyebaran informasi produk secara luas kepada konsumen, sehingga konsumen mengetahui dan mau mencoba produk yang kita pasarkan.

2. Pengembangan Design Produk, memperbanyak design produk baik dengan meniru produk maupun membuat design baru

3. Metode Pemasaran, menggunakan online market untuk memperluas pangsa pasar.

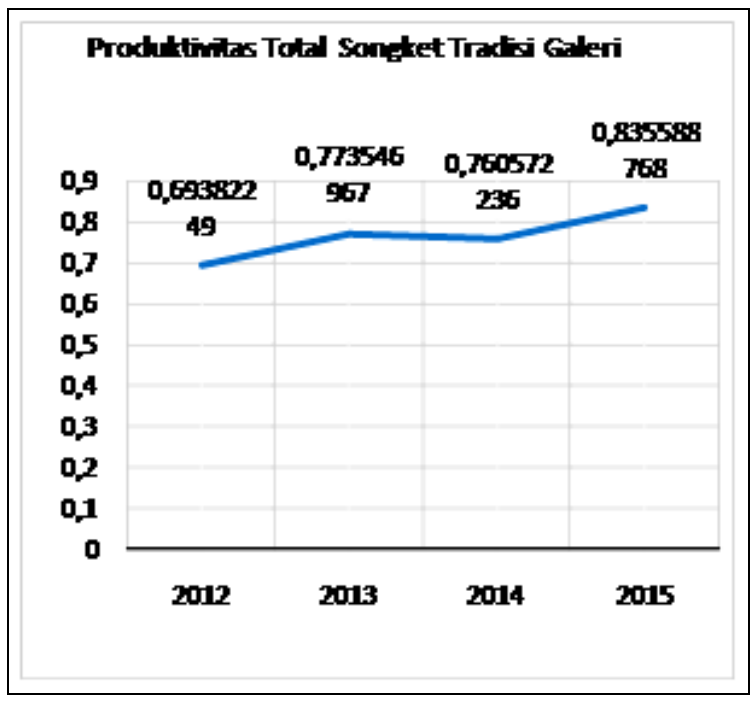

Gambar 5. Produktifitas total untuk UKM Songket tradisi galeri
Dari penerapan alternative yang telah kita rancang berupa menambah design dan penerapan e-comers, didapatkan data penjualan UKM 3 bulan terakhir. Dari data tersebut kita masukkan rumus produktivitas, untuk UKM Dimas terjadi peningkatan penjualan dari semua jenis sebesar $15 \%$, didapat peningkatan produktivitas. Dimana pada tahun pertama produktivitas partial material adalah 2,86 seterusnya untuk tahun kedua 3,28. Untuk UKM Songket Tradisis galeri terjadi peningkatan penjualan sebesar $10 \%$, dengan memasukan data terjadi peningkatan produktivitas total dari 0,76 pada tahun pertama menjadi 0,84 pada tahun ke dua

\section{KESIMPULAN}

1. UKM yang menjadi target implementasi adalah Dimas Silver dan Songket Tradisi Galery

2. Alternative yang dipilih adalah pengembangan design dan E- comers

3. Alternative yang diberikan mampu memberikan peningkatan produktivitas

\section{UCAPAN TERIMAKASIH}

Terima kasih penulis untuk Kemenristekdikti yang telah membiayai pelaksanaan penelitian hibah bersaing tahun 2016 .

\section{DAFTAR PUSTAKA}

Arman N., 2000, Perencanaan dan pengendalian produksi, Guna Widya Jakarta.

Gaspersz, 1998, Metode analisis untuk peningkatan kualitas, Gramedia PustakaUtama, Jakarta.

Indrayanti, 2012, Peran pemerintah dalam pengembangan UKM berorientasi ekspor (Studi kasus: Klaster Kasongan dalam Rantai Tambah Global), Jurnal Transnasional, 3(2).

Sumanth D.J., 1985, Productivity e ngineering and management, McGraw-Hill, Inc., Singapore.

Tanto D., Dewi S.M., Budio S.P., 2012, Faktorfaktor yang mempengaruhi produktivitas pekerja pada pengerjaan atap baja ringan di perumahan Green Hills Malang, Jurnal Rekayasa Sipil Universitas Brawijaya, 6(1). 